\title{
Feryal Saygilıgil, Nacide Berber (Eds.) Modern Türkiye'de Siyasi Düşünce, Cilt 10/ Feminizm (Political Thought in Modern Turkey, Volume 10 / Feminism), İstanbul: İletişim Yayınları, 2020, 880 s.
}

Büşra Bilgin*

Modern Türkiye'de Siyasi Düşünce: Feminizm başlıklı kitap, İletişim Yayınlarının "Modern Türkiye'de Siyasi Düşünce” başlığıyla hazırlanan 10 ciltlik edisyon çalışmasının son cildi olarak Aralık 2020 'de yayımlanmıştır. Aynı yayınevinin Cumhuriyet Türkiye'sinde öne çıkan ve siyasal açılımlara olanak sağlamış çeşitli düşünce akımlarını dönemler, aktörler, akımlar, söylemler ve tartışmalar çerçevesinde ele alan; "Tanzimat ve Meşrutiyetin Birikimi", "Kemalizm", "Modernleşme ve Batıcılık", "Milliyetçilik", "Muhafazakarlık", "İslâmcılık", "Liberalizm”, "Sol Düşünce", "Dönemler ve Zihniyetler" başlıklarına sahip dokuz ciltlik serisine yaklaşık on yll sonra onuncu cilt olarak "Feminizm" eklenmiştir. Feryal Saygılıgil ve Nacide Berber editörlüğünde hazırlanan 880 sayfalık bu çalışmaya seksen yazar tarafindan katkı sunulmuştur. Saygılıgil'in kendi ifadesiyle iki yılı aşkın bir çalışma sürecinin ürünü olan kitapta editörlerin asıl meselesi “...bu topraklarda XIX. yüzyıldan itibaren feminizme dair üretilen fikirleri bir araya getirmek...”tir. Bu fikirlerin nasıl, kimler tarafından, hangi şartlarda oluşturulduğunu anlayabilmeyi ve özneleri de ortaya çıkarmayı amaçlamışlardır. Oldukça hacimli bir çalışma olmasına rağmen Saygılıgil sunuş kısmında sayfa sınırı sebebiyle yer veremedikleri başlıklar ve yazarlar olduğunu belirtmiştir. Ona göre kitabın çalışma alanı öylesine ideolojik ve politiktir ki; sahanın kendi içindeki tartışmalarının yanında bugüne değin tartışılmış kavramlara, disiplinlere, akımlara, alanlara,

* Marmara Üniversitesi İlahiyat Fakültesi Din Sosyolojisi Ana Bilim Dalı Doktora Öğrencisi, busrakucukkayis@gmail.com, 0000-0002-9609-4018 
politikalara yeni bir bakışı ve belki de meydan okumayı gerektirmektedir (Saygılıgil, 2020: 20).

Kitabın içeriği kronolojik bir sırayı birebir takip etmekten ziyade kavramlar, temalar, tartışma alanları ve bunların birbirleriyle ilişkisi üzerinden inşa edilmiştir. Bu bakımdan her bir yazı bir diğerinden bağımsız olarak da açıklayıcı ve anlaşılabilir niteliktedir. Fikrî aktörlerin bağlam ve anlatılan konu dahilinde farklı yazılarda yeniden yer aldığını hatırda tutup kitap içinde bir isim odaklı okumayı buna göre yapmak elzemdir. Örneğin; geç dönem Osmanlı kadın hareketi temsilcilerinden Nezihe Muhiddin, Fatma Aliye, Nigâr Hanım gibi isimler hem başlangıçta tarihî serüvenin seyrinde anlatılmış hem de ilgili görülen "İslamî Feminizm Tartışmaları", "Edebiyatta Feminist Söz" gibi bölümlerde yeniden kendilerine yer bulmuştur. Yine kadın meselelerinde kendi dönemindeki muhafazakâr görüşleri sıkı biçimde eleştiren hatta sosyalist fikirleriyle öne çıkan Sabiha Sertel; muhafazakâr kadınların tahayyülü anlatısının hemen ardından hayatı ve görüşleriyle okuyucuya aktarılmıştır. Çalışmanın bu yönüyle kadın araştırmaları konusunda spesifik bir alanı merak eden/araştıran okuyucuya dahi bir şekilde kitabın çoğunluğuyla irtibat kurma zemini oluşturduğunu dolayısıyla alışılagelmiş bir fikir ansiklopedisi formundan hayli farklı olduğunu söylemek mümkündür.

Kitabın başlangıcında -tam anlamıyla kronolojik bir ilerleyişle olmamakla birlikte- feminist tarih yazıcılığı bağlamında geç dönem Osmanlı feminizmi irdelenmiş ve meşrutiyet dönemi yayınlarındaki kadın konulu tartışmalar gündem edilmiştir. Bu bölümlerde Müslüman Osmanlı kadını ile Ermeni ve Rum tebaaya mensup kadınların yazdıkları, söyledikleri ayrı ayrı bölümlendirilerek (ve kadınlar bu sıfatlarla özneleştirilerek) ele alınmıştır. Burada yer verilmiş “Osmanlı Ermeni Feminizmi: Zaber Asadur'un Nesi Radikaldi?” başlıklı yazıdaki şu ifadeler dikkat çekicidir:

“...Ermeni kadın özgürleşme hareketinin öncü isimlerinden bazllar kendilerini feminist olarak adlandırmadılar. Bunun farklı tarihlerde farklı sebepleri vardl. Bunlar arasında terimlerin henüz kullanılmaya başlamışolmaması, sadece Fransa'da belirli bir grup 
kadının kendilerine verdikleri ad olarak anlaşılmış olması, İngiltere, Fransa ve Avrupa'nın farklı ülkeleri ve Amerika'da yükselen hareketin fazla 'Batılı', modernist, burjuva ve 'aşırı' bireyci bulunması gibi farklı sebepler sayllabilir. Bugün bu kadınların hepsine feminist diyoruz çünkü onlar kadın oldukları için ezildiklerinin bilincindeydiler, kurumsallaşmış cinsiyetçiliğe karşı eleştirilerini kamusal alanda dile getirdiler ve kadının özgürleşmesini engelleyen cinsel politikaya son vermek için örgütlendiler...”(Bilal, 2020: 41)

Geç Osmanlı ve Erken Cumhuriyet devrinde yaşamış Ermeni kadınların aktivizmine dair aktarılan bu ifadeler Türkiye toprakları dahilindeki feminizmin okuduğumuz/dinlediğimiz tarihini başka bir açıdan değerlendirme imkânını gözden kaçırmamamız gerektiğini dolaylı biçimde göstermektedir. Bu kadınlar özelinde yine Osmanlı'daki Müslüman hak arayışındaki kadınlar arasında da kendisini feminist olarak adlandırmaktan kaçınan kadınların "tercih"lerini ve sebeplerini konuşmamız gerekmez mi? Dönemin şartlarında kendi iradelerini beyan edip ses veren bu kadınların talepleri yanında kaygılarını da anlama çabası göstermenin bugünkü farklı kadınlık durumlarını değerlendirebilmeyi de kolaylaştıracağı kanaatindeyim.

Erken dönem Müslüman Türk kadın hareketinin izi gazete ve dergiler üzerinden sürülmüş̧ bu bağlantı üzerinden yetmişli yıllar sonrasındaki feminizm tartışmaları da dergicilik temasıyla ele alınmıştır. Maddeci ve sosyalist feminizmin Türkiye'deki izdüşümleri de ilgili bölümlerde okuyucuya aktarılmıştır. 2000'ler sonrası feminist hareket ise hem dijital aktivizmle hem de televizyon ve yayılarda yükselen popüler feminizmin sesleriyle değerlendirilmiştir. Yine son birkaç yıldır özellikle sosyal medyada tanık olduğumuz feminizm-transfeminizm eksenli tartışmalar "Transfeminizm Dile Gelince: Her Şeyimiz Tamamdı Sanki, Bir Bizdik Noksan!' başlıklı bir yazıyla kitabın içinde yer almıştır. Bu bakımdan çalışmanın Türkiye'de feminizm tarihi yanında güncel tartışmaları ve gelecekte nereye evirileceğini de gündem haline getirdiği söylenebilir (Bilal vd., 2020: 198).

"İslamî Feminizm Tartışmaları" Türkiye özelinde Hidayet Şefkatli Tuksal'ın ana yazısı yanında Konca Kuriş, "İslamcı Kadın 
Hareketi” ve "Kadınlar Camilerde" hareketinin anlatıldığı yazılarla desteklenmiştir. İslamî feminizmi, XIX. yüzyıl sonlarındaki Müslüman kadınların tartışmalarına kadar geriye götüren Tuksal'ın bu değerlendirmesiyle kitabın birçok yerinde ilgili dönemin Türkiye'de örgütlü feminizmin ilk adımları sayılması ne ölçüde örtüşür; tartışmak gerekir. Kavramın İslam dünyası ölçeğinde Müslüman kadınlar tarafından nasıl alımlandığından kısaca bahseder, ardından kendi tecrübeleri ışığında Türkiye'de kavramın tartışılmasını ve kendilerini feminist olarak tanımlayan Müslüman kadınların oluşturduğu sivil inisiyatifleri anlatır. Yazının sonuç kısmında ise Alaine Tourainne'in "geçmişle gelecek arasında bir tercih yapmaya değil, bu ikisini bir araya getirmeye çalışan bir ülke" benzetmesini dindar kadınlarla eşleştirerek hem İslamî hem de seküler kesimin bu dindar kadınlardan hoşnut olmadığını söyler.

Türkiye'de İslamcı kadın hareketini feminizmle ilişkisi bağlamında ele alan Dinçer, "feminizme mesafeli duruş", "feminizmle ilişkilenme" ve "kadının insan hakları söylemi" şeklinde adlandırdığı üç yaklaşım üzerinden bu ilişkiyi kurgulamıştır. Müslüman yahut dindar kimliği yanında feminizmi de benimsemiş ve sahada yer almış kadınların kendilerini "Müslüman feminist yahut İslamî feminist" şeklinde tanımlamasında dahi sıfatların sıralanışına odaklanıp yine de öncelikle Müslüman olarak nitelendirmelerini vurgulaması ilginçtir. Bu durum "Feminizm kendisi dışında bir üst kimliği kabul etmez mi?” sorusunu ve üçüncü dalga tartışmalarını akla getirmektedir. Yine İslamcı kadınla feminizm ilişkisini tartıştığı şu ifadeler dikkat çekicidir:

“...28 Şubat sürecini yaşayan İslamcı kadınların söylemindeki modernizm eleştirisi çok belirgindir. Türban yasă̆ nedeniyle Kemalizm'e karşı barındırılan öfke, Kemalizm'in modernleşme ülküsü nedeniyle modernleşmeye de yönlendirilir. Modernizm eleştirisini 'tektipleştirici'liği üzerinden ele alan bu yaklaşımda, modernizm dolayısıyla Batı'nın 'eşitlik' anlayışı da kabul görmez. Feminizmi de modernizmle ilişkisi bağlamında değerlendiren İslamcı kadınlar bu nedenle feminizmle mesafeli olmalar gerektiğ konusunda nettirler." (Dinçer 2020: 244) 
Kadınların bahsi geçen tercihlerinin başörtüsü yasağı travması şeklinde yansıtılması meselenin yalnızca yüzeydekiler ekseniyle ele alındığının önemli bir göstergesidir. Feminizmle teorik ve pratik düzeyde tanımlanmayı reddetmenin kökenini öncelikle (yazıda bahsi geçen her kesimden dindar kadının yaptığı şekliyle) bu kadınların kendilerini birincil olarak ilişkilendirdiği inanç ekseninde de tahlil etmek gerekmez mi? Şimdiye değin yapılan çalışmalar ve süren tartışmalara yapılan gelişigüzel bir bakışla bile kadın ve erkeğin ontolojik düzlemdeki eşitliğinden sosyal manada birbirlerini tamamlayıcı rollerine kadar çok geniş bir zihinsel çerçeve ve gelenek birikimi; İslamcı kadınları anlama/anlamlandırma çabasına daha verimli bir katkı sunacaktır.

"Kemalist Feminizm: Kadın Hareketi Tarihinin Göz ArdıEdilmiş 'Bariz Gerçeğì' başlıklı yazıda ise Kemalist kadın hareketini mücadeleci bir kimlikle tasvir eden yazar, öte yandan kadın hakları aktivizmi içinde yer bulamamalarını "laikçiliğin gölgesinde, devletin güdümünde, sınıf körü ve antifeminist” olarak değerlendirilmeleri sebebiyle anlaşılabilir bulduğunu aktarır. Artık örgütlü kadın mücadelesi tarihinde bu kadınlara da yer verilmesini söyleyerek Şirin Tekeli’nin 1935-1980 yılları arasını çorak yıllar olarak nitelemesine karşı çıkar. Kemalist kadınların "feminist" kavramını kullanmamalarına rağmen kadının özgürleşmesini kendilerine gündem ettiklerini savunur (Çağatay, 2020: 330). Ancak birçok yazıda farklı kadınlık durumlarında dahi "feminist" sıfatını kabul etmenin birincil önemde sayıldığı hatta hangi kimliğini önceleyerek kendini tanımladığı bir veri haline gelirken Kemalist kadınların feminist sıfatını reddetmelerinin müşfik bir kabulle karşlanması dikkat çekicidir.

Kitapta yine kimlik üzerinden biçimlenen Alevi, Kürt, Muhafazakâr, Milliyetçive Sol/Sosyalist görüşlü kadınlara odaklanan farklı çalışmalar yer almaktadır. Türkiye'de feminizmin kurumsallaşması, sivil inisiyatifler, dergiler ve akademideki çalışmalar da çeşitli yazılarla okurlara sunulmuştur. Başlangıçta belirttiğim üzere tematik araştırmalar da kitabın önemli bir kısmını oluş̧urmaktadır. 
$\mathrm{Bu}$ bağlamda feminizm ve aile tartışmaları teori, politika ve pratik ilişkisi çerçevesinde değerlendirilmiş, "annelik" çift yönlü bir kavram olarak ele alınmıştır. Siyaset, akademi, edebiyat ve sanatta feminist kadınların izini süren yazılarla kitap tamamlanmıştır.

Modern Türkiye'de Siyasi Düşünce: Feminizm başlıklı kitap geniş hacmi, temas ettiği çok sayıda konu, kavram ve tarih itibariyle Türkiye'de kadın çalışmaları ve feminizm araştırmaları bağlamında önemli bir başvuru kaynağı olacaktır. Bu bağlamda hem yazıların içindeki dipnotlar hem de kitabın sonundaki uzun kaynakça araştırmacıları diğer birçok kaynağa yönlendirme vazifesini yürütecek genişliktedir. Ayrıca başlangıçta aktardığım üzere çalışmaya katkı sunan seksen yazarın bazıları saha içinde tanınırlığı yüksek isimler iken bazıları da genç araştırmacılardır. Özellikle genç isimlerin katkı sundukları yazıların çoğunun kendi lisansüstü araştırmaları ekseninde oluştuğu gözlemlenmektedir. Bu durum hem geçmiş araştırmaların derlenmesini hem de bugünün konuşulmasını sağlarken gelecekte oluşacak tartışmaların da işaret fişeğini taşımaktadır. Elbette bu seksene yakın yazı içinde mutlak bir söz birliği olduğunu iddia etmek abes olacaktır ancak bazı hususlarda örtük kabulleri görmemek de elde değildir. Yine de kadın araştırmaları sahasında yeni açılımların oluşabilmesi, farklı kadınlık durumlarının konuşulabilmesi için bir adım olma ihtimali saklı tutulmalıdır. 